Article

\title{
Determination of Uric Acid in Co-Presence of Dopamine and Ascorbic Acid Using Cuprous Oxide Nanoparticle-Functionalized Graphene Decorated Glassy Carbon Electrode
}

\author{
Jingheng Ning ${ }^{1,+}$, Quanguo He ${ }^{2,+}$, Xin Luo ${ }^{1}$, Min Wang ${ }^{1}$, Donglin Liu ${ }^{1}$, Jianhui Wang ${ }^{1, *}$, \\ Guangli $\mathrm{Li}^{2}$ and Jun Liu ${ }^{2}$ \\ 1 School of Chemistry and Biological Engineering, Changsha University of Science \& Technology, \\ Changsha 410114, China; ningjingheng@126.com (J.N.); luoxin_gl@126.com (X.L.); \\ wang_min1993@126.com (M.W.); donglin993@163.com (D.L.) \\ 2 Hunan Key Laboratory of Biomedical Nanomaterials and Devices, School of Life Sciences and Chemistry, \\ Hunan University of Technology, Zhuzhou 412007, China; hequanguo@126.com (Q.H.); \\ guangli010@163.com (G.L.); liu.jun.1015@163.com (J.L.) \\ * Correspondence: wangjh0909@csust.edu.cn; Tel.: +86-731-8525-8039 \\ + These authors contributed equally to this work.
}

Received: 31 August 2018; Accepted: 19 September 2018; Published: 20 September 2018

\begin{abstract}
Cuprous oxide nanoparticles $\left(\mathrm{Cu}_{2} \mathrm{O}\right.$ NPs) were dispersed into a graphene oxide (GO) solution to form a homogeneous $\mathrm{Cu}_{2} \mathrm{O}-\mathrm{GO}$ dispersion. After this, the cuprous oxide nanoparticles were functionalized to electrochemically reduce the graphene oxide decorated glassy carbon electrode $\left(\mathrm{Cu}_{2} \mathrm{O}-\mathrm{ErGO} / \mathrm{GCE}\right)$. This was prepared by coating the $\mathrm{Cu}_{2} \mathrm{O}-\mathrm{GO}$ dispersion onto the surface of the glassy carbon electrode (GCE), which was followed by a potentiostatic reduction process. An irreversible two-electron reaction of uric acid (UA) was observed at the voltammetric sensor. Moreover, the high concentrations of dopamine (DA) and ascorbic acid (AA) hardly affected the peak current of UA, which suggested that $\mathrm{Cu}_{2} \mathrm{O}-\mathrm{ErGO} / \mathrm{GCE}$ have excellent selectivity for UA. This is probably because the response peaks of the three compounds are well-separated from each other. The oxidation peak current was proportional to the concentration of UA in the ranges of $2.0 \mathrm{nM}-0.6 \mu \mathrm{M}$ and $0.6 \mu \mathrm{M}-10 \mu \mathrm{M}$, respectively, with a low limit of detection ( $/ \mathrm{N}=3,1.0 \mathrm{nM})$ after an accumulation time of 120 s. $\mathrm{Cu}_{2} \mathrm{O}-\mathrm{ErGO} / \mathrm{GCE}$ was utilized for the rapid detection of UA in human blood serum and urine samples with satisfactory results.
\end{abstract}

Keywords: cuprous oxide; graphene; uric acid; modified electrode; biosensor

\section{Introduction}

Uric acid (UA) is a metabolite of nucleoprotein and nucleic acid. Having excessive amounts of UA in the human body can cause gout, renal failure and congenital hyperuricemia [1,2]. Therefore, the quantitative analysis of UA in the physiological fluids is of great importance in drug control and clinical diagnosis. Various methods have been developed for UA detection, such as spectrofluorometry [3], chromatography [4,5], enzymatic methods [6,7], chemiluminescence [8] and electroanalytical methods. Among these techniques, electrochemical methods are very suitable for the practical detection of UA due to their unique superiorities, including low cost, high sensitivity and good selectivity. The electrochemical determination of UA is commonly based on monitoring the oxidation signal of UA on the electrode. The electrooxidation process of UA is illustrated in Scheme 1 [9]. However, it is susceptible to interference from coexisting species, such as dopamine (DA) and ascorbic acid (AA), 
when detecting UA with bare electrodes since they have similar oxidation peak potentials [10-12]. Nanocomposite-modified electrodes can improve the anti-interference performance and selectivity, which is a common method that is used to solve this problem. At present, many chemically modified electrodes have been proposed for the determination of UA [9,13-22] although their selectivity is limited, especially due to the coexistence of DA and AA. Hence, developing a modified electrode with high sensitivity and selectivity to meet clinical demands is still challengeable and desirable.<smiles></smiles>

Scheme 1. The reaction mechanism of UA.

In the past few years, transition metals and metal oxides have received increasing attention in many fields, such as sensors and electrocatalysis, due to their unique sensing performance and superior electrocatalytic activity $[9,11,23,24]$. Among these metal oxides, cuprous oxide $\left(\mathrm{Cu}_{2} \mathrm{O}\right)$ is a new type of p-type semiconductor with a narrow band gap, which can also be easily excited by visible light. Due to their outstanding advantages, such as non-toxic, low cost and stable photochemical properties, $\mathrm{Cu}_{2} \mathrm{O}$ nanoparticles have been extensively used in many fields, such as new energy, photocatalytic degradation, sterilization and sensing [25-27]. The different morphologies of $\mathrm{Cu}_{2} \mathrm{O}$ nanomaterials, such as hollow spheres, cubes, wires, octahedrons and cages, can be synthesized by adjusting the synthesis conditions [28]. At present, various electrochemical sensors based on $\mathrm{Cu}_{2} \mathrm{O}$ nanoparticles have been constructed for the detection of $\mathrm{H}_{2} \mathrm{O}_{2}$ [29,30], glucose [30-32], dopamine [33-35], herbicide paraquat [36], L-tyrosine [37], vanillin [38], sunset yellow [39] and $\mathrm{NO}_{2}$ [40]. As far as we know, the use of $\mathrm{Cu}_{2} \mathrm{O}$ for the determination of $\mathrm{UA}$ has rarely been reported in the literature. However, $\mathrm{Cu}_{2} \mathrm{O}$ nanoparticles are easily agglomerated, which greatly limits their application in electrochemical sensors. How to reduce the agglomeration of nano-semiconductors is an urgent problem to be solved.

Graphene (GR) is a single-layer two-dimensional planar crystal with the specific surface area of $2630 \mathrm{~m}^{2} / \mathrm{g}$, which enables it to be an ideal template for GR-based composites in the fields of battery, photocatalysis, sensing and so on [41]. $\mathrm{Xu}$ et al. [29] successfully prepared $\mathrm{Cu}_{2} \mathrm{O}$-reduced graphene oxide nanocomposites using three various methods (namely physical adsorption, in-situ reduction and one-pot synthesis). The composites were dispersed in $0.1 \%$ nafion solution and decorated on the glassy carbon electrode (GCE) by a drop-coating technique, which were constructed for nonenzymatic hydrogen peroxide sensing. $\mathrm{Cu}_{2} \mathrm{O} / \mathrm{GR}$ nanocomposites were also successfully prepared by a solvothermal method [33], with $\mathrm{Cu}_{2} \mathrm{O} / \mathrm{GR} / \mathrm{GCE}$ having showed good electrocatalytic activity towards DA. As result, the proposed $\mathrm{Cu}_{2} \mathrm{O} / \mathrm{GR} / \mathrm{GCE}$ exhibited excellent sensing performances in terms of linear range $(0.1-10 \mu \mathrm{M})$ and limit of detection (LOD, $10 \mathrm{nM})$. Ye et al. [36] developed a novel paraquat sensor based on $\mathrm{Cu}_{2} \mathrm{O}$ / polyvinyl pyrrolidone-functionalized GR nanosheet nanocomposite. However, the preparation of the above GR-based composites is complicated, which greatly affects the use of sensors in practical applications. Therefore, the development of a green routine for the creation of $\mathrm{Cu}_{2} \mathrm{O}-\mathrm{GR}$ composite-based electrochemical sensors is very crucial.

Herein, a simple and green routine was proposed to construct an ultrasensitive sensor based on $\mathrm{Cu}_{2} \mathrm{O}$ /electrochemically reduced graphene oxide decorated glass carbon electrode $\left(\mathrm{Cu}_{2} \mathrm{O}-\mathrm{ErGO} / \mathrm{GCE}\right)$, which aimed to selectively detect UA even in the co-presence of DA and AA. The $\mathrm{Cu}_{2} \mathrm{O}$-loaded graphene oxide (GO) nanocomposites were directly coated on the electrode surface, before being electrochemically reduced to obtain $\mathrm{Cu}_{2} \mathrm{O}-\mathrm{ErGO} / \mathrm{GCE}$. The as-obtained $\mathrm{Cu}_{2} \mathrm{O}-\mathrm{ErGO}$ has excellent electrocatalytic activity towards UA oxidation and thus, we have successfully realized the selective and sensitive detection of UA in human blood serum and urine samples. 


\section{Results and Discussion}

\subsection{Characterization of Surface Morphologies}

The morphologies of $\mathrm{Cu}_{2} \mathrm{O}, \mathrm{GO}$ and $\mathrm{Cu}_{2} \mathrm{O}$-ErGO nanocomposites were recorded by Scanning Electron Microscope (SEM) (Figure 1). Figure 1A shows the SEM image of the $\mathrm{Cu}_{2} \mathrm{O}$ nanoparticles. Most of these $\mathrm{Cu}_{2} \mathrm{O}$ nanoparticles had a spherical outline, with an average diameter of around $100 \mathrm{~nm}$ based on the SEM measurements of 500 nanoparticles. Figure 1B shows the low magnification SEM image of GO nanosheets, which clearly illustrates the flake-like shapes. Furthermore, the thickness of the wrinkled edges could be regarded as the thickness of the exfoliated GO nanosheets, which displayed a thickness about 2-20 nm. The GO at a high magnification (inset of Figure 1B) had a wrinkled surface, which corrugated and scrolled in a similar way to crumpled silk veils. This lamellar structure of GO can effectively increase the specific surface area of the modified electrode. Figure $1 \mathrm{C}$ clearly shows that a large number of $\mathrm{Cu}_{2} \mathrm{O}$ nanoparticles were decorated on a thin film of electrochemically reduced graphene oxide (ErGO), indicating the $\mathrm{Cu}_{2} \mathrm{O}$ nanoparticles successfully combined with the graphene support. Besides, the SEM image in Figure $1 \mathrm{C}$ revealed that these particles have a similar morphology and size to the $\mathrm{Cu}_{2} \mathrm{O}$ particles in Figure 1A, indicating that the introduction of ErGO did not change the structure of $\mathrm{Cu}_{2} \mathrm{O}$. The $\mathrm{Cu}_{2} \mathrm{O}-\mathrm{ErGO}$ nanocomposite is expected to improve the catalytic activity and sensitivity due to the catalytic activity of $\mathrm{Cu}_{2} \mathrm{O}$ and large surface area of GO [42].

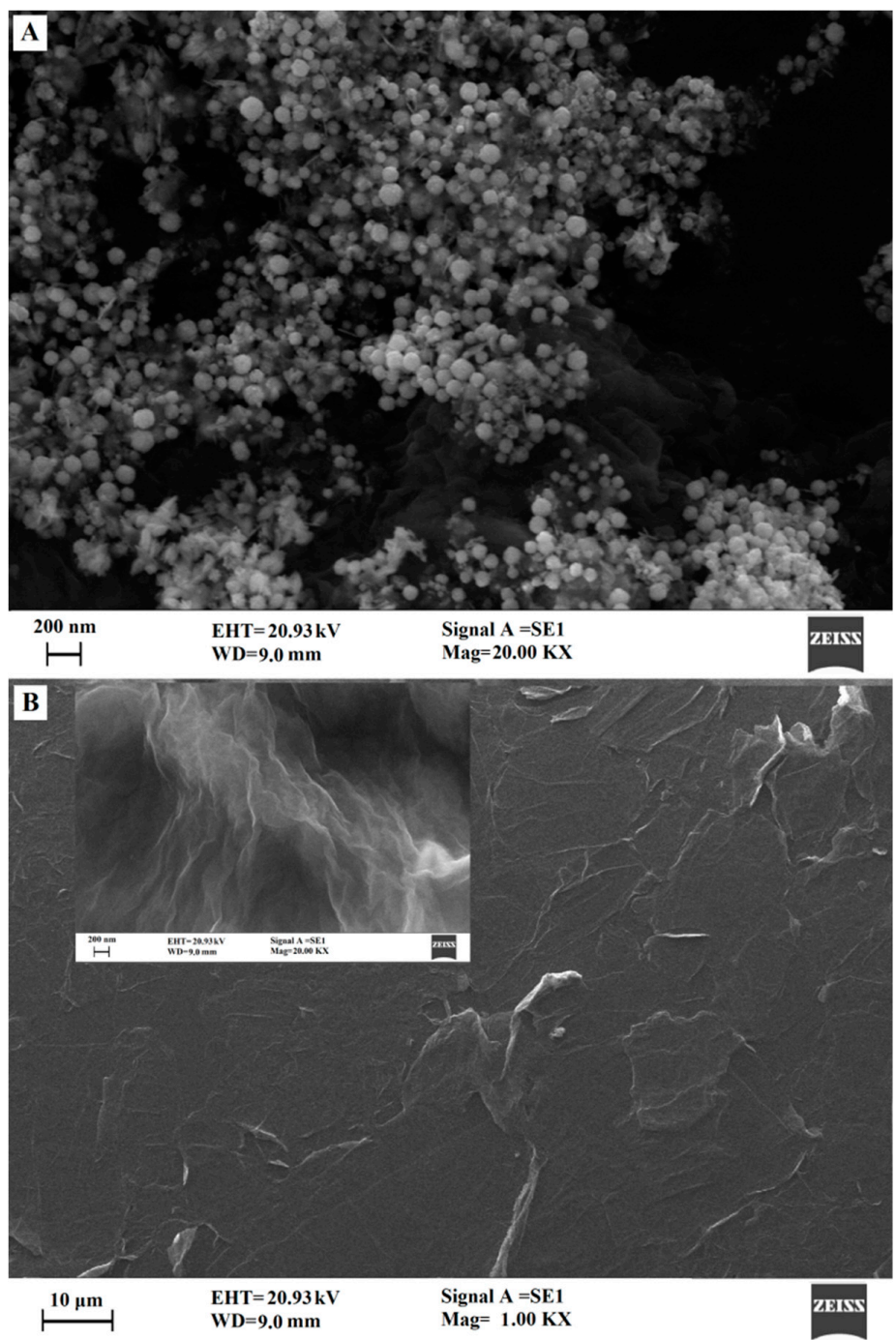

Figure 1. Cont. 


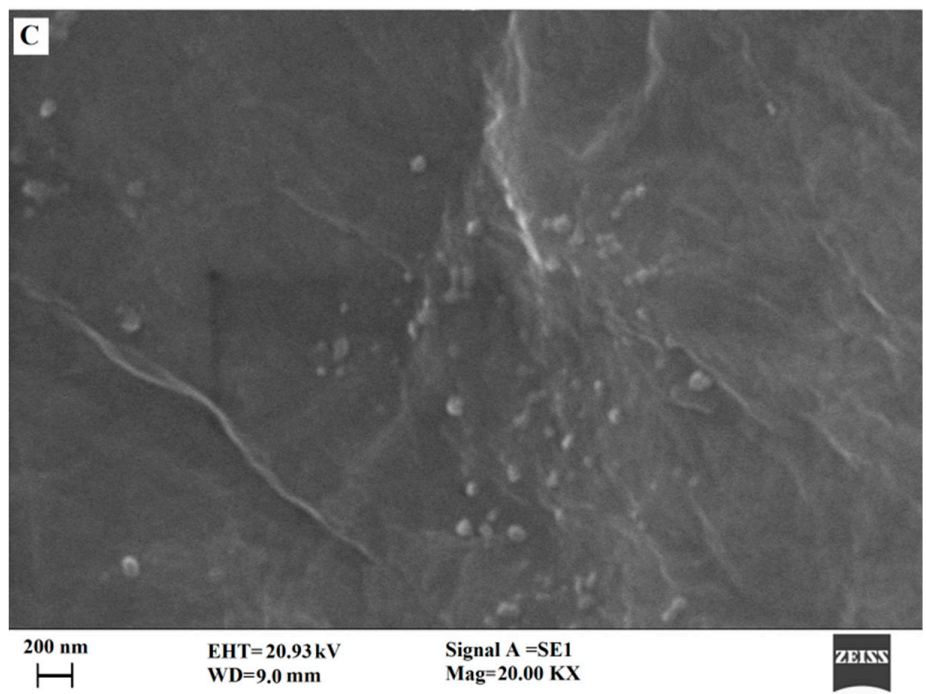

Figure 1. SEM photos of (A) $\mathrm{Cu}_{2} \mathrm{O}$ nanoparticles; (B) $\mathrm{GO}$ nanosheets at low magnification and at high magnification (inset); and $(\mathrm{C}) \mathrm{Cu}_{2} \mathrm{O}$-ErGO composites.

\subsection{Voltammetric Responses of UA on Different Electrodes}

The voltammetric behavior of $10 \mu \mathrm{M}$ UA on the bare GCE, GO/GCE, ErGO/GCE and $\mathrm{Cu}_{2} \mathrm{O}-\mathrm{ErGO} / \mathrm{GCE}$ was measured in $0.1 \mathrm{M}$ phosphate buffer solution (PBS, $\mathrm{pH}$ of 3.0) by cyclic voltammetry (CV). Only one oxidation peak was observed on all electrodes (Figure 2), which indicated that the electrochemical reaction of UA is completely irreversible. On the bare GCE, a broad and weak oxidation peak was observed at $0.683 \mathrm{~V}$ with a oxidation peak current $\left(I_{\mathrm{pa}}\right)$ of $5.413 \mu \mathrm{A}$, corresponding to a slow electron transfer kinetic process. On the GO/GCE, the oxidation potential $\left(E_{\mathrm{pa}}\right)$ moves positively to $0.705 \mathrm{~V}$ and the $I_{\mathrm{pa}}$ decreases to $1.315 \mu \mathrm{A}$. This phenomenon is closely related to the retarded electron transfer due to the presence of poor electrical conductivity of GO. When decorated with ErGO, the $I_{\mathrm{pa}}$ of UA increases obviously $\left(I_{\mathrm{p} a}=30.89 \mu \mathrm{A}\right)$ and the $E_{\mathrm{pa}}$ shifts negatively to $0.580 \mathrm{~V}$, showing that ErGO has good electrocatalytic activity towards UA. This is probably due to the large specific surface area and excellent electrical conductivity of ErGO, which eventually increases the response current of $\mathrm{UA}$. When decorated with the $\mathrm{ErGO}-\mathrm{Cu}_{2} \mathrm{O}$ nanocomposites, the sharp oxidation peak appears with the $E_{\mathrm{pa}}$ further shifting negatively to $0.561 \mathrm{~V}$ and the $I_{\mathrm{pa}}$ further increasing to $57.69 \mu \mathrm{A}$. The $I_{\mathrm{pa}}$ for $\mathrm{Cu}_{2} \mathrm{O}-\mathrm{ErGO} / \mathrm{GCE}$ is about 10-fold higher than that on the bare GCE and almost twice as large as that at the ErGO/GCE, which is due to the synergistic effect of ErGO and $\mathrm{Cu}_{2} \mathrm{O}$ nanoparticles.

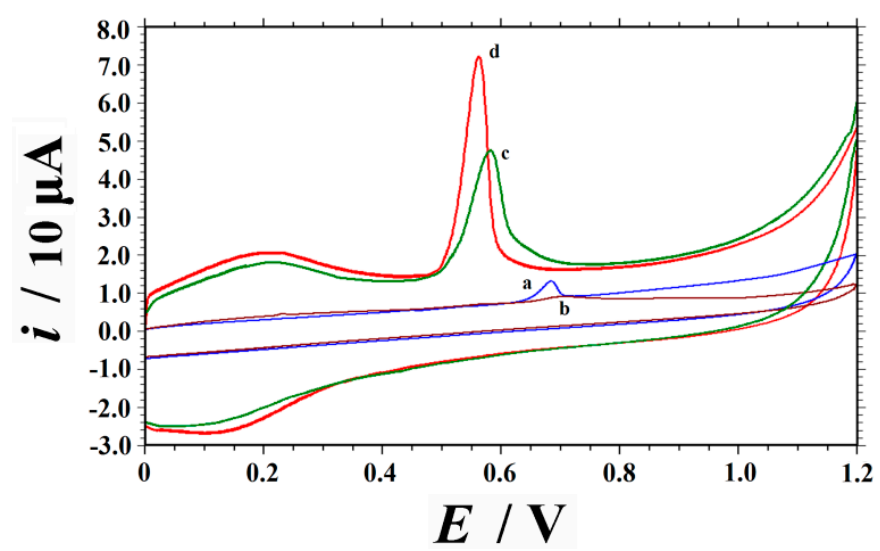

Figure 2. CVs of $10 \mu \mathrm{M}$ UA at different electrodes measured in 0.1 M PBS (pH of 3.0); (a) GCE, (b) GO/GCE, (c) ErGO/GCE and (d) $\mathrm{Cu}_{2} \mathrm{O}-\mathrm{ErGO} / \mathrm{GCE}$. Accumulation potential: $-0.2 \mathrm{~V}$, accumulation time: $30 \mathrm{~s}$ and sweep rate: $0.1 \mathrm{~V} \mathrm{~s}^{-1}$. 


\section{3. $p H$-Dependent Electrochemical Response}

The influence of the solution $\mathrm{pH}$ on the voltammetric responses of $10 \mu \mathrm{M} \mathrm{UA}$ at $\mathrm{Cu}_{2} \mathrm{O}-\mathrm{ErGO} / \mathrm{GCE}$ was investigated by $C V$. The variation of $E_{\mathrm{pa}}$ and $I_{\mathrm{pa}}$ with the solution $\mathrm{pH}$ values are shown in Figure 3 . The $E_{\mathrm{pa}}$ of UA shifts negatively with an increase in the $\mathrm{pH}$, suggesting that the protons $\left(\mathrm{H}^{+}\right)$are involved in the oxidation of UA. Moreover, $E_{\mathrm{pa}}$ is linearly related to the $\mathrm{pH}$, while the corresponding regression equation is $E_{\mathrm{pa}}(\mathrm{V})=-0.0548 \mathrm{pH}+0.7304(\mathrm{r}=0.9977)$. The slope $(54.8 \mathrm{mV} / \mathrm{pH})$ approaches the theoretical value of $57.6 \mathrm{mV} / \mathrm{pH}$, implying that the equal number of electrons and protons take part in the UA oxidation. The $I_{\mathrm{pa}}$ of UA increases gradually with an increase in the $\mathrm{pH}$, before reaching a maximum in the $\mathrm{pH}$ range of 2.7-3.1. After this, the $I_{\mathrm{pa}}$ decreases with a further increase in the $\mathrm{pH}$. It is well known that the electrochemical behavior of $\mathrm{UA}\left(\mathrm{pK}_{\mathrm{a} 1}=2.38\right.$ and $\left.\mathrm{pK}_{\mathrm{a} 2}=9.39\right)$ is dependent on the $\mathrm{pH}$ value of the aqueous solution. In an acidic solution, $\mathrm{UA}$ is positively charged due to the protonation of the amino group, which is available to form strong hydrogen bonds with oxygen-containing groups on ErGO surface, such as carboxyl groups and carbonyl groups. This ultimately improves the adsorption of UA onto the electrode surface. Considering the sensitivity of the detection, a $\mathrm{pH}$ of 3.0 is recommended for UA determination.

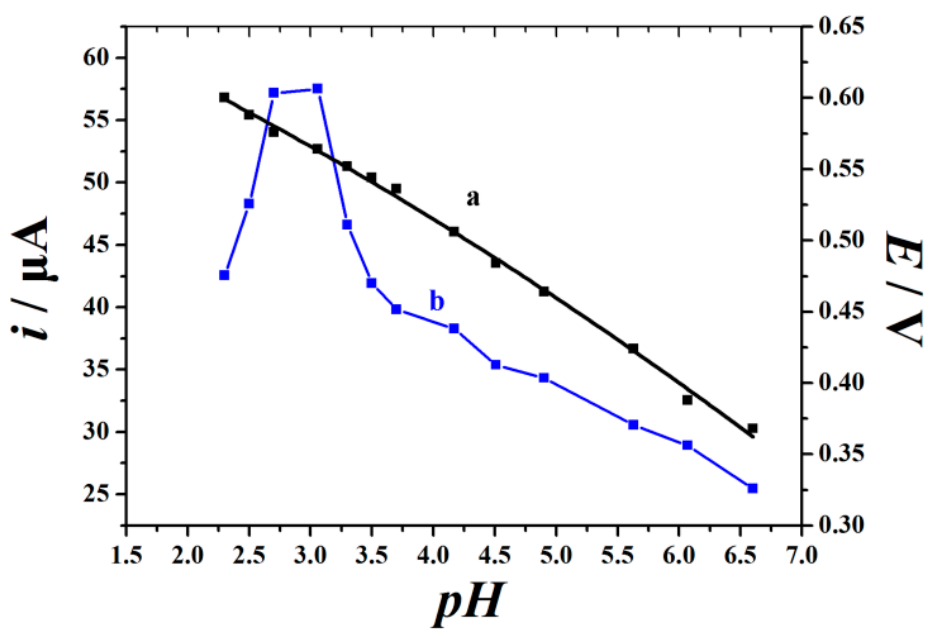

Figure 3. The influence of $\mathrm{pH}$ on the voltammetric response of $10 \mu \mathrm{M}$ UA on $\mathrm{Cu}_{2} \mathrm{O}$-ErGO/GCE. The plots of the $E_{\mathrm{pa}}$ against $\mathrm{pH}(\mathbf{a})$ and $I_{\mathrm{pa}}$ against $\mathrm{pH}(\mathbf{b})$. Supporting electrolyte: $0.1 \mathrm{M}$ PBS; Accumulation potential: $-0.2 \mathrm{~V}$, accumulation time: $30 \mathrm{~s}$ and scan rate: $0.1 \mathrm{~V} \mathrm{~s}^{-1}$.

\subsection{Sweep Rate and Electrochemical Kinetics}

The electrochemical kinetics of UA oxidation at $\mathrm{Cu}_{2} \mathrm{O}-\mathrm{ErGO} / \mathrm{GCE}$ was investigated by $\mathrm{CV}$, which was measured at various sweep rates. As presented in Figure 4, the $I_{\mathrm{pa}}$ has a positive linear relationship with the sweep rates $(v)$, while the corresponding linear relationship can be expressed as $I_{\mathrm{pa}}(\mu \mathrm{A})$ $=497.32 v\left(\mathrm{~V} \mathrm{~s}^{-1}\right)+5.2533(\mathrm{r}=0.9984)$. This indicates that the oxidation of UA is controlled by the adsorption process. The diffusion or adsorption-controlled behavior was also cross-verified by plotting $\log I_{\mathrm{pa}}$ vs. $\log v$, which yielded a linear regression equation of $\log I_{\mathrm{pa}}(\mu \mathrm{A})=0.8841 \log v\left(\mathrm{~V} \mathrm{~s}^{-1}\right)+2.6319$ $(\mathrm{r}=0.9987)$. The obtained slope (0.8841) is close to 1.0, which further confirms that the reaction is adsorption-controlled. Furthermore, the $E_{\mathrm{pa}}$ has a linear relationship to the Napierian logarithm of sweep rate $(\ln v)$. The linear regression equation is $E_{\mathrm{p}}(\mathrm{V})=0.0219 \ln v\left(\mathrm{~V} \mathrm{~s}^{-1}\right)+0.6117(\mathrm{r}=0.9974)$. For a completely irreversible and adsorption-controlled process, the electron transferred number (n) was calculated to be 2 according to Laviron's theory [43]. Combining with the pH-dependent response results, the UA oxidation is a 2-electron and 2-proton process. This is consistent with previous reports [12,21]. 


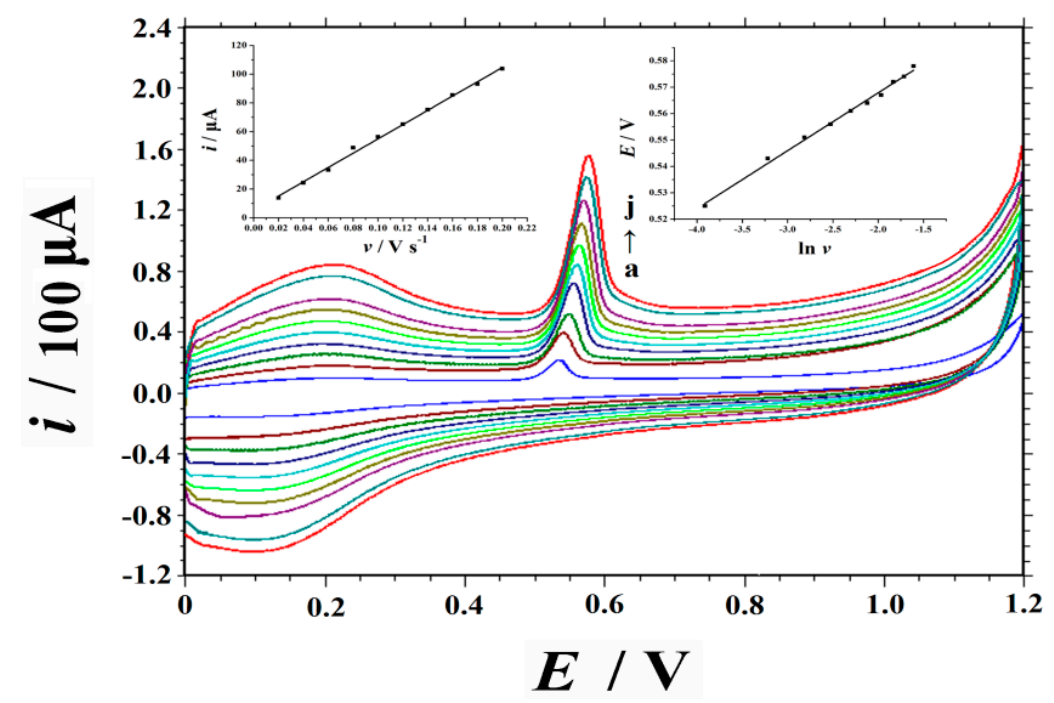

Figure 4. $\mathrm{CVs}$ of $10 \mu \mathrm{M} \mathrm{UA}$ at $\mathrm{Cu}_{2} \mathrm{O}-\mathrm{ErGO} / \mathrm{GCE}$ measured at various sweep rates (From a to j: 0.02, $0.04,0.06,0.08,0.10,0.12,0.14,0.16,0.18$ and $0.2 \mathrm{~V} \mathrm{~s}^{-1}$, respectively). The inset contains the plots of the peak current against sweep rate (left) and the peak potential against Napierian logarithm of sweep rate (right).

\subsection{Optimization of the Analytical Conditions}

\subsubsection{Optimization of Supporting Electrolytes}

The influence of different supporting electrolytes on the $I_{\mathrm{pa}}$ of $10 \mu \mathrm{M} \mathrm{UA}$ at $\mathrm{Cu}_{2} \mathrm{O}-\mathrm{ErGO} / \mathrm{GCE}$ was investigated. PBS ( $\mathrm{pH}$ of 2.3-6.6), $\left(\mathrm{CH}_{2}\right)_{6} \mathrm{~N}_{4}-\mathrm{HCl}$ buffer ( $\mathrm{pH}$ of 4.0-6.0), HAc-NaAc buffer ( $\mathrm{pH}$ of 3.0-6.0), $\mathrm{HAc}-\mathrm{NH}_{4} \mathrm{Ac}$ buffer ( $\mathrm{pH}$ of 3.0-6.0), $\mathrm{NH}_{3}-\mathrm{NH}_{4} \mathrm{Cl}$ buffer ( $\mathrm{pH}$ of 8.0-10.0), $\mathrm{H}_{2} \mathrm{SO}_{4}, \mathrm{HCl}$ and $\mathrm{H}_{3} \mathrm{PO}_{4}$ (all concentrations of $0.1 \mathrm{M}$ ) were used as the supporting electrolytes. The sharp oxidation peak with the largest $I_{\mathrm{pa}}$ was found in $0.1 \mathrm{M}$ PBS.

\subsubsection{Optimization of Accumulation Conditions}

As demonstrated in Section 2.4, the oxidation of $\mathrm{UA}$ at $\mathrm{Cu}_{2} \mathrm{O}-\mathrm{ErGO} / \mathrm{GCE}$ is an adsorption-controlled process. Therefore, the accumulation can increase the adsorption capacity of UA on the electrode surface and significantly enhance the sensitivity of the detection. The influence of the accumulation potential on the $I_{\mathrm{pa}}$ of $U A$ is plotted in Figure $5 \mathrm{~A}$. When the accumulation potential varied from -0.3 to $0.1 \mathrm{~V}$, the $I_{\mathrm{pa}}$ altered very slightly. However, the $I_{\mathrm{pa}}$ of UA decreases rapidly when the accumulation potential shifts to the positive and exceeds $0.1 \mathrm{~V}$. The influence of the accumulation time was also investigated, with the results presented in Figure 5B. During 0-120 s, the $I_{\mathrm{pa}}$ of UA increases significantly over time, before leveling off. This is mainly related to the saturation adsorption of UA on the electrode surface. Therefore, the accumulation was performed at $-0.2 \mathrm{~V}$ for $120 \mathrm{~s}$ before the electrochemical measurement or detection.

\subsection{Analytic Properties}

\subsubsection{Calibration Curves, Dynamical Response Regions and Detection Limit}

Under the optimal experimental conditions, the $I_{\mathrm{pa}}$ of UA with different concentrations at $\mathrm{Cu}_{2} \mathrm{O}-\mathrm{ErGO} / \mathrm{GCE}$ was measured by Second-order derivative linear sweep voltammetry (SDLSV) (Figure 6). The $I_{\mathrm{pa}}$ of UA increases linearly with an increase in the concentration in the ranges of $2.0 \mathrm{nM}-0.6 \mu \mathrm{M}$ and $0.6 \mu \mathrm{M}-10 \mu \mathrm{M}$. The corresponding linear equations for these two ranges are $I_{\mathrm{pa}}(\mu \mathrm{A})$ $=8.6267 c(\mu \mathrm{M})+0.1289(\mathrm{r}=0.9971)$ and $I_{\mathrm{pa}}(\mu \mathrm{A})=13.467 c(\mu \mathrm{M})-4.3026(\mathrm{r}=0.9996)$, respectively. The detection limit $(\mathrm{S} / \mathrm{N}=3)$ is found to be $1.0 \mathrm{nM}$. Compared with the existing nanocomposite-modified 
electrodes (Table 1), $\mathrm{Cu}_{2} \mathrm{O}$-ErGO/GCE has a lower limit of detection and is suitable for the detection of UA at a lower concentration level.
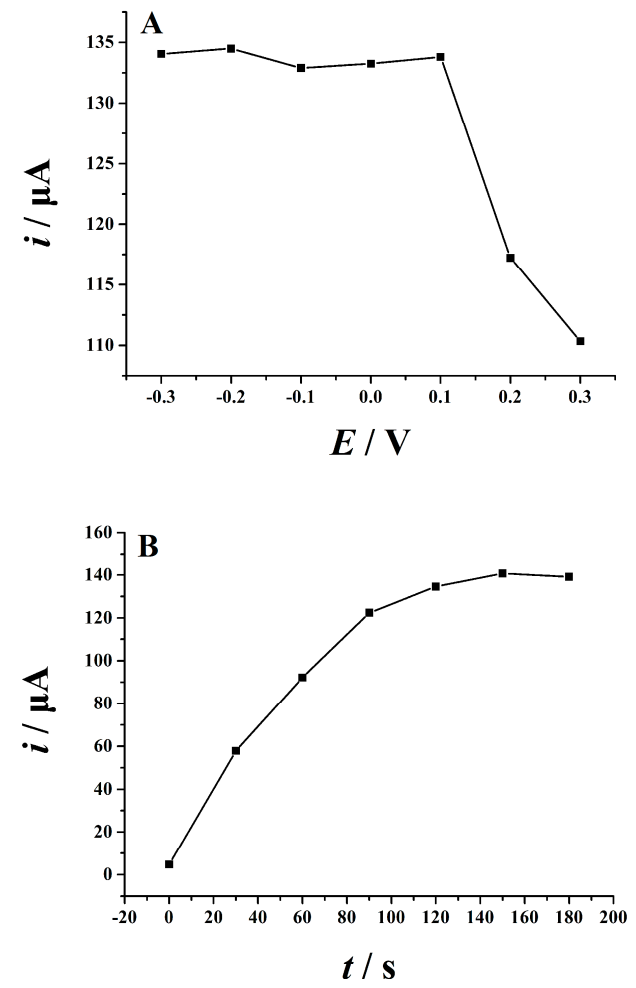

Figure 5. The influence of accumulation potential (A, accumulation time $=120 \mathrm{~s})$ and accumulation time $(\mathbf{B}$, accumulation potential $=120 \mathrm{~s})$ on the peak current of $10 \mu \mathrm{M}$ UA. Sweep rate: $0.1 \mathrm{~V} \mathrm{~s}^{-1}$.
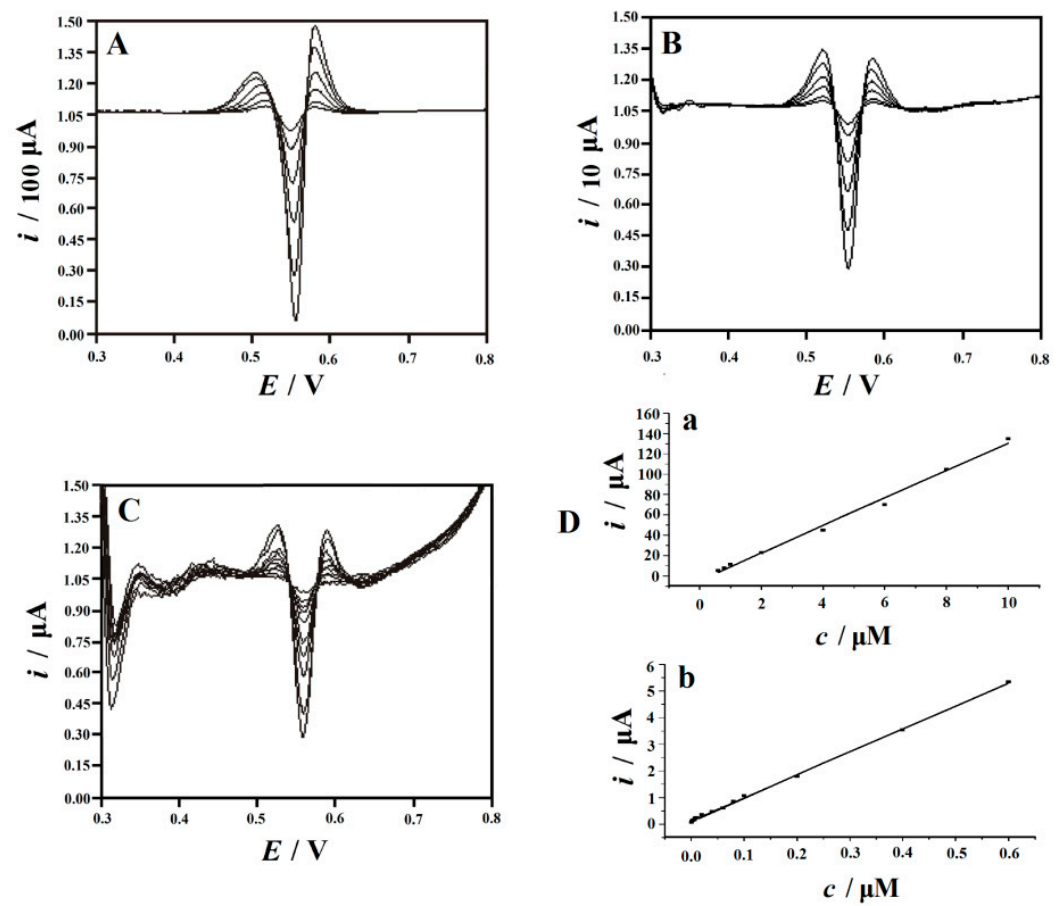

Figure 6. SDLSV recorded on the $\mathrm{Cu}_{2} \mathrm{O}-\mathrm{ErGO} / \mathrm{GCE}$ in $0.1 \mathrm{M} \mathrm{PBS}(\mathrm{pH}=3.0)$ containing various concentrations of UA. (A) From inner to outer: 1, 2, 4, 6, 8 and $10 \mu \mathrm{M}$; (B) From inner to outer: 0.1, 0.2, 0.4, 0.6, 0.8 and $1.0 \mu \mathrm{M}$; (C) From inner to outer: 0.002, 0.004, 0.006, 0.008, 0.01, 0.02, 0.04, 0.06, 0.08 and $0.10 \mu \mathrm{M}$; (D) Linear relationship between the oxidation peak currents and the concentration of UA: (a) 0.6 10 $\mu \mathrm{M}$ and (b) 0.002 0.6 $\mu \mathrm{M}$. Accumulation at $-0.2 \mathrm{~V}$ for $120 \mathrm{~s}$; Sweep rate: $0.1 \mathrm{~V} \mathrm{~s}^{-1}$. 
Table 1. Characteristics of various voltammetric sensors for the detection of uric acid.

\begin{tabular}{|c|c|c|c|c|c|c|c|c|}
\hline Electrodes & Techniques & Supporting Electrolyte & $\begin{array}{l}\text { Working } \\
\text { Potential }\end{array}$ & $\begin{array}{c}\text { Linear } \\
\text { Range/ } \mu \mathrm{M}\end{array}$ & $\begin{array}{l}\text { Detection } \\
\text { Limit/ } / \mu \mathrm{M}\end{array}$ & $\begin{array}{l}\text { Repeatability } \\
\text { (RSD\%) }\end{array}$ & Stability & Ref. \\
\hline a $\mathrm{PD}-\mathrm{Cu}(\mathrm{II}) / \mathrm{GCE}$ & ${ }^{1} \mathrm{DPV}$ & $0.1 \mathrm{M}^{\circ} \mathrm{PBS}(\mathrm{pH} 7.5)$ & $+0.4 \mathrm{~V}$ vs. SCE & $60-1680$ & 24.6 & 1.6 & $\begin{array}{c}5.8 \% \text { loss after } 28 \\
\text { days }\end{array}$ & [12] \\
\hline b PSA-ERCG/GCE & DPV & $0.1 \mathrm{M} \mathrm{NH}_{3}-\mathrm{NH}_{4} \mathrm{Cl}(\mathrm{pH} 9.0)$ & $\begin{array}{l}+0.016 \mathrm{~V} \text { vs. } \\
\text { SCE }\end{array}$ & $0.02-15$ & 0.012 & 2.8 & $\begin{array}{c}10 \% \text { loss after } 2 \\
\text { weeks }\end{array}$ & [13] \\
\hline${ }^{c} \mathrm{P}-4-\mathrm{ABA} / \mathrm{GCE}$ & DPV & $0.2 \mathrm{M}$ PBS (pH 4.5) & $\begin{array}{l}+0.576 \mathrm{~V} \text { vs. } \\
\mathrm{Ag} / \mathrm{AgCl}\end{array}$ & $1.0-80.0$ & 0.5 & 3.1 & $\begin{array}{l}2.3 \% \text { loss after } 1 \\
\text { week }\end{array}$ & [14] \\
\hline d Trp-GR/GCE & DPV & 0.1 M PBS (pH 7.0) & $\begin{array}{l}+0.355 \mathrm{~V} \text { vs. } \\
\mathrm{Ag} / \mathrm{AgCl}\end{array}$ & 10-1000 & 1.24 & 5.92 & $\begin{array}{c}2.77 \% \text { loss after } 1 \\
\text { week and } 6.91 \% \text { in } 2 \\
\text { weeks }\end{array}$ & [15] \\
\hline e Au-RGO/GCE & DPV & $0.1 \mathrm{M}$ PBS (pH 7.0) & $+0.26 \mathrm{~V}$ vs. SCE & $8.8-53$ & 1.8 & 2.0 & $5 \%$ loss after 1 week & [16] \\
\hline${ }^{\mathrm{f}} \mathrm{PDDA}-\mathrm{G} / \mathrm{CPE}$ & DPV & $0.1 \mathrm{M}$ PBS (pH 7.0) & $\begin{array}{l}+0.18 \mathrm{~V} \text { vs. } \\
\mathrm{Ag} / \mathrm{AgCl}\end{array}$ & $0.5-20$ & 0.08 & 3.6 & $\begin{array}{c}10.1 \% \text { loss after } 20 \\
\text { days }\end{array}$ & [17] \\
\hline $\begin{array}{c}\mathrm{g} \text { poly } \\
(\mathrm{Tyr}) / \mathrm{MWCNTs}-\mathrm{COOH} / \mathrm{GCE}\end{array}$ & DPV & 0.1 M PBS (pH 7.4) & $+0.30 \mathrm{~V}$ vs. SCE & $1.0-350$ & 0.30 & 3.0 & Not mentioned & [18] \\
\hline${ }^{\mathrm{h}}$ MWCNT-HoFNPs-CH/GCE & ${ }^{\mathrm{m}} \mathrm{CV}$ & $0.1 \mathrm{M}^{\mathrm{p}} \mathrm{DCAABS}(\mathrm{pH} 1.0)$ & $\begin{array}{l}+0.605 \mathrm{~V} \text { vs. } \\
\quad \text { SCE }\end{array}$ & $0.2-500.0$ & 0.16 & 1.19 & $\begin{array}{l}\text { No significant } \\
\text { change after } 6 \\
\text { months }\end{array}$ & [19] \\
\hline${ }^{\mathrm{i}} \mathrm{PAO} / \mathrm{GH} / \mathrm{GCE}$ & DPV & 0.1 M PBS (pH 6.5) & $\begin{array}{l}+0.260 \mathrm{~V} \text { vs. } \\
\text { SCE }\end{array}$ & $0.1-1000$ & 0.02 & 2.2 & $\begin{array}{l}7.0 \% \text { loss after } 1 \\
\text { month }\end{array}$ & [20] \\
\hline${ }^{\mathrm{k}}$ Nano-Au-PMT/GCE & DPV & $0.1 \mathrm{M}$ PBS (pH 7.0) & $+0.37 \mathrm{~V}$ vs. SCE & $0.07-1.0$ & 0.045 & Not mentioned & $\begin{array}{c}12.0 \% \text { loss after } 2 \\
\text { weeks }\end{array}$ & [22] \\
\hline $\mathrm{Cu}_{2} \mathrm{O}-\mathrm{ErGO} / \mathrm{GCE}$ & ${ }^{\mathrm{n}} \mathrm{LSV}$ & 0.1 M PBS (pH 3.0) & $0.561 \mathrm{~V}$ vs. SCE & $0.002-0.6,0.6-10$ & 0.001 & 2.2 & $\begin{array}{c}7.6 \% \text { loss after } 2 \\
\text { weeks }\end{array}$ & This work \\
\hline
\end{tabular}

a PD-Cu(II)/GCE: polydopamine-Cu(II)-modified glassy carbon electrode; ${ }^{\text {b }}$ PSA-ERCG/GCE: poly(sulfosalicylic acid) and electroreduced carboxylated graphene-modified glassy carbon electrode; ${ }^{c}$ P-4-ABA/GCE: poly(4-aminobutyric acid)-modified glassy carbon electrode; ${ }^{\mathrm{d}}$ Trp-GR/GCE: tryptophan-functionalized graphene nanocomposite-modified glassy carbon electrode; ${ }^{\mathrm{A}} \mathrm{Au}-\mathrm{RGO} / \mathrm{GCE}:$ Au nanoplates and reduced graphene oxide-modified glassy carbon electrode; ${ }^{\mathrm{f}}$ PDDA-G/CPE: poly(diallyldimethylammonium chloride)-functionalized graphene modified carbon paste electrode; ${ }^{\mathrm{g}}$ poly (Tyr)/MWCNTs-COOH/GCE: poly (tyrosine)-functionalized multi-walled carbon nanotubes composite film-modified glassy carbon electrode; ${ }^{\mathrm{h}}$ MWCNT-HoFNPs-CH/GCE: multiwalled carbon nanotubes-holmium fluoride nanoparticles-chitosan composite film-modified glassy carbon electrode; ${ }^{1}$ PAO/GH/GCE: poly (acridine orange)/graphene-modified glassy carbon electrode; ${ }^{j}$ LaHCF/GCE: hexacyanoferrate lanthanum film-modified glassy carbon electrode; ${ }^{k}$ Nano-Au-PMT/GCE: poly(L-methionine)/gold nanoparticle-modified glassy carbon electrode; ${ }^{l}$ DPV: differential pulse voltammetry; ${ }^{\mathrm{m}} \mathrm{CV}$ : cyclic voltammetry; ${ }^{\mathrm{n}} \mathrm{LSV}$ : linear sweep voltammetry; ${ }^{\circ}$ PBS: phosphate buffer solution; ${ }^{\mathrm{P}}$ DCAABS: dichloroacetic acid buffer solution. 


\subsubsection{Interference}

As we all know, AA, DA and UA always coexist in the biological fluids, such as blood and urine. Hence, the interference effect of AA and DA on UA detection was first studied. The CV response of $10 \mu \mathrm{M}$ UA in the presence of $1 \mathrm{mM}$ AA and $50 \mu \mathrm{M}$ DA is illustrated in Figure 7A. A broad and small peak appears at $430 \mathrm{mV}$ at the bare GCE, indicating the very close peak potentials of AA, DA and UA at the bare electrode so that the simultaneous detection of the three compounds is difficult to achieve. On the contrary, the oxidation peaks of the three species were well separated at both ErGO/GCE and $\mathrm{ErGO}-\mathrm{Cu}_{2} \mathrm{O} / \mathrm{GCE}$. For $\mathrm{ErGO}-\mathrm{Cu}_{2} \mathrm{O} / \mathrm{GCE}$, the peak potential separation $\left(\Delta E_{\mathrm{p}}\right)$ between DA and UA is greater, while the $I_{\mathrm{pa}}$ of UA is much higher than DA and AA. The SDLSV of DA, UA and AA at ErGO- $\mathrm{Cu}_{2} \mathrm{O} / \mathrm{GCE}$ is shown in Figure 7B. The $\Delta E_{\mathrm{p}}$ for AA-DA, DA-UA are $0.262 \mathrm{~V}$ and $0.152 \mathrm{~V}$, respectively. The large $\Delta E_{\mathrm{p}}$ is favorable for the accurate detection of UA without interference. Other possible interferents, such as glucose, purine, oxalate, citrate and urea (all concentrations of $1.0 \mathrm{mM}$ ), were also examined. The variation of $I_{\mathrm{pa}}$ is not beyond $\pm 5 \%$, indicating no significant interference even in the presence of these potential interfering substances. Therefore, $\mathrm{Cu}_{2} \mathrm{O}-\mathrm{ErGO} / \mathrm{GCE}$ exhibits good selectivity for the detection of UA.
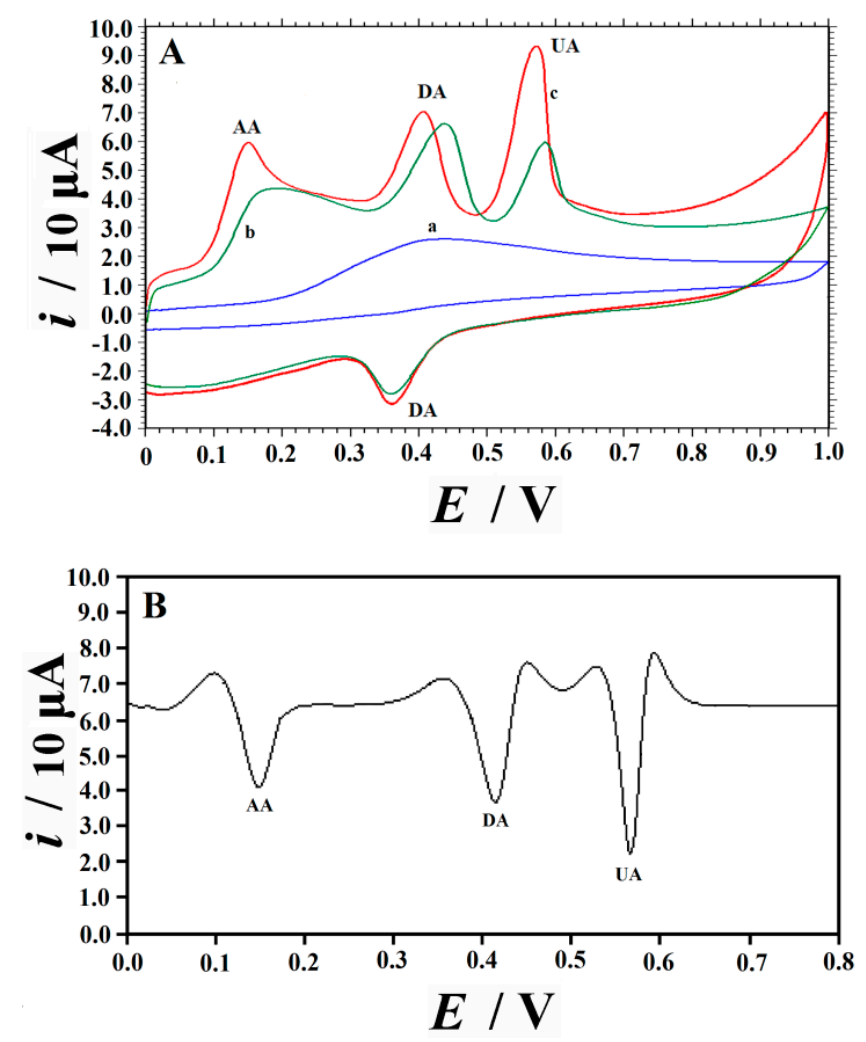

Figure 7. (A) CV measured on the bare GCE (a), ErGO/GCE (b) and $\mathrm{Cu}_{2} \mathrm{O}-\mathrm{ErGO} / \mathrm{GCE}$ (c) in $0.1 \mathrm{M}$ PBS $(\mathrm{pH}=3.0$ ) containing the mixture of $1.0 \mathrm{mM}$ AA, $50 \mu \mathrm{M}$ DA and $10 \mu \mathrm{M}$ UA; (B) SDLSV of the mixture of $1.0 \mathrm{mM}$ AA, $50 \mu \mathrm{M}$ DA and $10 \mu \mathrm{M}$ UA obtained at $\mathrm{Cu}_{2} \mathrm{O}-\mathrm{ErGO} / \mathrm{GCE}$.

\subsubsection{Repeatability, Reproducibility and Stability}

The repeatability of $\mathrm{Cu}_{2} \mathrm{O}-\mathrm{ErGO} / \mathrm{GCE}$ was validated by ten parallel measurements of the $I_{\mathrm{pa}}$ of $10 \mu \mathrm{M}$ UA. The relative standard deviation (RSD) is $2.2 \%$, suggesting the good repeatability of $\mathrm{Cu}_{2} \mathrm{O}-\mathrm{ErGO} / \mathrm{GCE}$. The precision of multiple $\mathrm{Cu}_{2} \mathrm{O}-\mathrm{ErGO} / \mathrm{GCEs}$ was also investigated. Seven $\mathrm{Cu}_{2} \mathrm{O}-\mathrm{ErGO} / \mathrm{GCEs}$ were fabricated by the same procedure independently and the RSD is calculated as $4.8 \%$, which suggested that the electrode fabrication method has good reproducibility. Finally, the stability of $\mathrm{Cu}_{2} \mathrm{O}-\mathrm{ErGO} / \mathrm{GCE}$ was also evaluated. The ErGO-Cu $\mathrm{u}_{2} \mathrm{O} / \mathrm{GCE}$ was placed at $4{ }^{\circ} \mathrm{C}$ in a 
refrigerator for 2 weeks. After two weeks, the $I_{\mathrm{pa}}$ of $10 \mu \mathrm{M} \mathrm{UA}$ retains $92.4 \%$ of the initial response current, indicating that the $\mathrm{Cu}_{2} \mathrm{O}-\mathrm{ErGO} / \mathrm{GCE}$ has good stability.

\subsubsection{Real Sample Analysis}

Under the optimal analytical conditions, $\mathrm{Cu}_{2} \mathrm{O}-\mathrm{ErGO} / \mathrm{GCE}$ was used for the detection of UA in human serum and urine by SDLSV. The serum samples was provided by a local hospital and the urine samples were collected from students in our group. A total of $1.0 \mathrm{~mL}$ was taken from each sample, before being diluted with $0.1 \mathrm{M}$ PBS (pH 3.0) in a 100-mL and 500-mL flask. The sample solutions were measured by the SDLSV method. The results are listed in Table 2. The samples were spiked with UA standard solution at levels similar to those found in the samples. The recoveries ranged from $97.5 \%$ to $102.8 \%$, which indicates that this method can meet the requirements for the detection of UA in the actual samples.

Table 2. Determination of uric acid in human serum and urine samples.

\begin{tabular}{cccccc}
\hline Samples & a Detected/ $\boldsymbol{\mu M}$ & Added $/ \boldsymbol{\mu M}$ & $\begin{array}{c}\text { Total } \\
\text { Found/ } \boldsymbol{\mu M}\end{array}$ & Recovery/\% & $\begin{array}{c}\mathbf{b} \text { Content } \\
\text { Detected/mM }\end{array}$ \\
\hline urine 1 & $3.488( \pm 0.084)$ & 3.0 & $6.527( \pm 0.144)$ & 101.3 & $1.744( \pm 0.042)$ \\
urine 2 & $3.637( \pm 0.087)$ & 4.0 & $7.535( \pm 0.165)$ & 97.5 & $1.819( \pm 0.044)$ \\
urine 3 & $5.142( \pm 0.118)$ & 5.0 & $10.046( \pm 0.210)$ & 98.1 & $2.571( \pm 0.059)$ \\
serum 1 & $2.483( \pm 0.065)$ & 2.0 & $4.522( \pm 0.108)$ & 102.0 & $0.248( \pm 0.006)$ \\
serum 2 & $4.336( \pm 0.095)$ & 4.0 & $8.446( \pm 0.186)$ & 102.8 & $0.434( \pm 0.010)$ \\
serum 3 & $3.210( \pm 0.067)$ & 3.0 & $6.162( \pm 0.142)$ & 98.4 & $0.321( \pm 0.007)$ \\
\hline
\end{tabular}

${ }^{a}$ The results are expressed as mean value \pm S.D. based on four replicates $(n=4) .{ }^{b}$ The value of content is obtained by multiplying the detected value by the dilution factor of 100 for serum samples and 500 for urine samples.

\section{Experimental}

\subsection{Reagents and Solutions}

$\mathrm{CuSO}_{4} \cdot 5 \mathrm{H}_{2} \mathrm{O}, \mathrm{NaOH}$, hydrazine hydrate solution $(80 \mathrm{wt} \%$ ), graphite powder, polyvinyl pyrrolidone (PVP) and $\mathrm{H}_{2} \mathrm{O}_{2}$ solution ( $30 \mathrm{wt} \%$ ) were obtained from Sinopharm Chemical Reagent Co. Ltd. (Shanghai, China). AA, DA and UA were supplied by Sigma-Aldrich Co. (St. Louis, MO, USA). All the reagents were of analytical grade. The stock solution of $0.01 \mathrm{M}$ UA was prepared by dissolving the UA solid into a small volume of $0.1 \mathrm{M} \mathrm{NaOH}$ solution, before this was diluted to reach the desired concentration. Doubly distilled water was used in all experiments.

\subsection{Synthesis of $\mathrm{Cu}_{2} \mathrm{O}$ Nanoparticles}

According to a previous report [38], $\mathrm{Cu}_{2} \mathrm{O}$ nanoparticles $\left(\mathrm{Cu}_{2} \mathrm{O}\right.$ NPs) were synthesized by the wet-chemical method. Following a typical process, $100 \mathrm{mg}$ of $\mathrm{CuSO}_{4} \cdot 5 \mathrm{H}_{2} \mathrm{O}$ and $50 \mathrm{mg}$ of PVP were added into $20 \mathrm{~mL}$ of $\mathrm{H}_{2} \mathrm{O}$ with stirring. After this, $4 \mathrm{~mL}$ of $\mathrm{NaOH}(0.2 \mathrm{M})$ was added dropwise to form a blue precipitate. In the end, $15 \mu \mathrm{L}$ of hydrazine hydrate solution ( $80 \mathrm{wt} \%$ ) was added and the mixture was agitated at room temperature for $20 \mathrm{~min}$. The solid product was separated from the solution by centrifugation. After this, the product was cleaned with anhydrous alcohol and water, before being vacuum-dried at $60{ }^{\circ} \mathrm{C}$ overnight.

\subsection{Preparation of $\mathrm{GO}$ and $\mathrm{Cu}_{2} \mathrm{O}-\mathrm{GO}$ Composite}

Graphene oxide (GO) was synthesized according to our previous report [34]. Typically, concentrated $\mathrm{H}_{2} \mathrm{SO}_{4}(23 \mathrm{~mL})$ was cooled to $0{ }^{\circ} \mathrm{C}$, before graphite powder $(0.5 \mathrm{~g})$ and $\mathrm{NaNO}_{3}(0.5 \mathrm{~g})$ were added with mechanical stirring. $\mathrm{KMnO}_{4}(3.0 \mathrm{~g})$ was added slowly at a control temperature below $5{ }^{\circ} \mathrm{C}$, before the temperature was raised to $35^{\circ} \mathrm{C}$ and the mixture was stirred for $2 \mathrm{~h}$ to form a mash. Subsequently, $40 \mathrm{~mL}$ of water was slowly added into the solution at a temperature below $50^{\circ} \mathrm{C}$, before the temperature was increased to $95^{\circ} \mathrm{C}$ and the mixture was stirred for $0.5 \mathrm{~h}$. After $100 \mathrm{~mL}$ of water 
was added, the above solution was added into $20 \mathrm{~mL}$ of $30 \% \mathrm{H}_{2} \mathrm{O}_{2}$ in batches. The suspension was treated by suction filtration in time and the precipitate was washed with $150 \mathrm{~mL}$ of hydrochloric acid (1:10) and $150 \mathrm{~mL}$ of $\mathrm{H}_{2} \mathrm{O}$, respectively. The graphite oxide was obtained by drying under a vacuum at $50{ }^{\circ} \mathrm{C}$ overnight. Finally, $100 \mathrm{mg}$ pf graphite oxide were dispersed in $100 \mathrm{~mL}$ of water and exfoliated to GO by ultrasonication for $2 \mathrm{~h}$. After this, the golden-yellow supernatant with a concentration of about $1 \mathrm{mg} / \mathrm{mL}$ was obtained after centrifugation. A total of $1.0 \mathrm{mg}$ of $\mathrm{Cu}_{2} \mathrm{O}$ NPs was added into $20 \mathrm{~mL}$ pf GO $(1 \mathrm{mg} / \mathrm{mL})$ and mixed under ultrasonication for $2 \mathrm{~h}$. Finally, a homogeneous dispersion of $\mathrm{Cu}_{2} \mathrm{O}-\mathrm{GO}$ was obtained.

\subsection{Fabrication of $\mathrm{Cu}_{2} \mathrm{O}-\mathrm{ErGO} / \mathrm{GCE}$}

First, bare GCE was polished by $0.3 \mu \mathrm{m}$ of alumina slurry, before being rinsed by absolute ethanol and water in an ultrasonic bath for $3 \mathrm{~min}$ and dried in $\mathrm{N}_{2}$ blowing. Five $\mu \mathrm{L}$ of $\mathrm{Cu}_{2} \mathrm{O}-\mathrm{GO}$ dispersion was dropped on the freshly prepared GCE. After drying under ambient conditions, the $\mathrm{Cu}_{2} \mathrm{O}-\mathrm{GO} / \mathrm{GCE}$ was obtained. The $\mathrm{Cu}_{2} \mathrm{O}-\mathrm{GO} / \mathrm{GCE}$ was immersed in $0.1 \mathrm{M}$ PBS (pH of 6.0), before being electrochemically reduced at $-1.2 \mathrm{~V}$ for $120 \mathrm{~s}$ to obtain $\mathrm{Cu}_{2} \mathrm{O}-\mathrm{ErGO} / \mathrm{GCE}$. For comparison, GO/GCE and ErGO/GCE were fabricated by the similar procedures.

\subsection{Characterization and Measurements}

The SEM photos of $\mathrm{Cu}_{2} \mathrm{O}$ NPs, $\mathrm{GO}$ nanosheets and $\mathrm{Cu}_{2} \mathrm{O}-\mathrm{ErGO}$ nanocomposites were obtained by scanning electron microscopy (FESEM, EVO10, Carl Zeiss, Jena, Germany). The electrochemical behaviors of $\mathrm{UA}$ on the $\mathrm{Cu}_{2} \mathrm{O}$-ErGO/GCE was measured by cyclic voltammetry $(\mathrm{CV})$ and second-order derivative linear sweep voltammograms (SDLSV). Both the CV and SDLSV swept at a rate of $100 \mathrm{mV} / \mathrm{s}$. The potential sweep ranges were $0.0-1.2 \mathrm{~V}$ for $\mathrm{CV}$ and $0.3-0.8 \mathrm{~V}$ for SDLSV. The supporting electrolyte used was 0.1 M PBS (pH of 3.0) except where stated otherwise. All the electrochemical tests were performed on a CHI 660D electrochemical workstation (Chenhua Instrument Co. Ltd., Shanghai, China). The SDLSV were obtained from the JP-303E polarographic analyzer (Chengdu Instrument Factory, Chengdu, China). All the electrochemical experiments were carried out with a three-electrode system where the $\mathrm{Cu}_{2} \mathrm{O}$-ErGO/GCE (3-mm inner diameter) served as the working electrode, while $\mathrm{Pt}$ wire and saturated calomel electrode (SCE) acted as the counter electrode and reference electrode. The $\mathrm{pH}$ was measured by a $\mathrm{pH}$ meter (Shanghai Leichi Instrument Factory, Shanghai, China). The measurements were carried out at room temperature.

\section{Conclusions}

A novel electrochemical sensor based on cuprous oxide nanoparticles-electrochemically reduced graphene oxide nanocomposites decorated electrode $\left(\mathrm{Cu}_{2} \mathrm{O}-\mathrm{ErGO} / \mathrm{GCE}\right)$ was developed for the sensitive and selective detection of $\mathrm{UA}$. The $\mathrm{Cu}_{2} \mathrm{O}-\mathrm{ErGO} / \mathrm{GCE}$ was prepared by a green and convenient routine that combined the drop-casting method with the electrochemical reduction method. The graphene can effectively load $\mathrm{Cu}_{2} \mathrm{O}$ NPs and promote the electron transfer between electrode and analytes due to its specific surface area and good conductivity. The proposed sensor shows high electrocatalytic activity towards the oxidation of UA. Moreover, the $\mathrm{Cu}_{2} \mathrm{O}-\mathrm{ErGO} / \mathrm{GCE}$ can selectively detect UA even in the presence of high concentrations of DA and AA. Considering its distinct advantages, including simplicity, rapidness, high selective and sensitive as well as good repeatability, reproducibility and stability, the proposed $\mathrm{Cu} 2 \mathrm{O}-\mathrm{ErGO} / \mathrm{GCE}$ shows great potential for the detection of UA in the physiological samples.

Author Contributions: J.N. and J.W. conceived and designed the experiment and drafted the manuscript. M.W. and X.L. carried out the preparation and characterization of nanoparticles. N.H., D.L., G.L. and J.L. tested the electrochemical property. J.N., Q.H. supervised the study and participated in confirmation of the final draft. All authors read and approved the final manuscript.

Funding: This research was funded by the NSFC (No. 21505005 and 61703152), Hunan Provincial Natural Science Foundation (No. 2018JJ2424 and 2018JJ3134), the National Key R\&D Program of China (2017YFC1600306), and 
the Huxiang Youth Talent Support Program (2015RS4051), Project of Science and Technology Plan in Zhuzhou (201706-201806), The key Project of Department of Education of Guangdong Province (2016GCZX008)and Opening Project of Key Discipline of Materials Science in Guangdong (CNXY2017001, CNXY2017002 and CNXY2017003).

Conflicts of Interest: The authors declare no conflict of interest.

\section{References}

1. Alderman, M.; Aiyer, K.J.V. Uric acid: Role in cardiovascular disease and effects of losartan. Curr. Med. Res. Opin. 2004, 20, 369-379. [CrossRef] [PubMed]

2. He, Q.; Liu, J.; Liang, J.; Liu, X.; Li, W.; Liu, Z.; Ding, Z.; Tuo, D. Towards Improvements for Penetrating the Blood-Brain Barrier-Recent Progress from a Material and Pharmaceutical Perspective. Cell 2018, 7, 24. [CrossRef] [PubMed]

3. Marquardt, R.R. A simple spectrophotometric method for the direct determination of uric acid in avian excreta. Poult. Sci. 1983, 62, 2106-2108. [CrossRef] [PubMed]

4. Dai, X.; Fang, X.; Zhang, C.; Xu, R.; Xu, B. Determination of serum uric acid using high-performance liquid chromatography (hplc)/isotope dilution mass spectrometry (id-ms) as a candidate reference method. J. Chromatogr. B 2007, 857, 287-295. [CrossRef] [PubMed]

5. George, S.K.; Dipu, M.T.; Mehra, U.R.; Singh, P.; Verma, A.K.; Ramgaokar, J.S. Improved hplc method for the simultaneous determination of allantoin, uric acid and creatinine in cattle urine. J. Chromatogr. B 2006, 832, 134-137. [CrossRef] [PubMed]

6. Gjorup, S.; Poulsen, H.; Prætorius, E. The uric acid concentration in serum determined by enzymatic spectrophotometry. Scin. J. Clin. Lab. Investig. 1955, 7, 201-203. [CrossRef]

7. Prætorius, E.; Poulsen, H. Enzymatic Determination of Uric Acid with Detailed Directions. Scand. J. Clin. Lab. Investig. 1953, 5, 273-280. [CrossRef]

8. Yu, J.; Wang, S.; Ge, L.; Ge, S. A novel chemiluminescence paper microfluidic biosensor based on enzymatic reaction for uric acid determination. Biosens. Bioelectron. 2011, 26, 3284-3289. [CrossRef] [PubMed]

9. Huang, L.; Jiao, S.; Li, M. Determination of uric acid in human urine by eliminating ascorbic acid interference on copper (ii)-polydopamine immobilized electrode surface. Electrochim. Acta 2014, 121, 233-239. [CrossRef]

10. He, Q.; Li, G.; Liu, X.; Liu, J.; Deng, P.; Chen, D. Morphologically tunable $\mathrm{MnO}_{2}$ nanoparticles fabrication, modelling and their influences on electrochemical sensing performance toward dopamine. Catalysts 2018, 8 , 323. [CrossRef]

11. He, Q.; Liu, J.; Liang, J.; Liu, X.; Tuo, D.; Li, W. Chemically Surface Tunable Solubility Parameter for Controllable Drug Delivery-An Example and Perspective from Hollow PAA-Coated Magnetite Nanoparticles with R6G Model Drug. Materials 2018, 11, 247. [CrossRef] [PubMed]

12. He, Q.; Liu, J.; Liu, X.; Li, G.; Deng, P.; Liang, J.; Chen, D. Sensitive and selective detection of tartrazine based on $\mathrm{TiO}_{2}$-electrochemically reduced graphene oxide composite-modified electrodes. Sensors 2018, 18, 1911. [CrossRef] [PubMed]

13. Yan, H.; Xiao, H.; Xie, Q.; Liu, J.; Sun, L.; Zhou, Y.; Zhang, Y.; Chao, L.; Chen, C.; Yao, S. Simultaneous electroanalysis of isoniazid and uric acid at poly(sulfosalicylic acid)/electroreduced carboxylated graphene modified glassy carbon electrode. Sens. Actuators B Chem. 2015, 207, 167-176. [CrossRef]

14. Zheng, X.; Zhou, X.; Ji, X.; Lin, R.; Lin, W. Simultaneous determination of ascorbic acid, dopamine and uric acid using poly(4-aminobutyric acid) modified glassy carbon electrode. Sens. Actuators B Chem. 2013, 178, 359-365. [CrossRef]

15. Lian, Q.; He, Z.; He, Q.; Luo, A.; Yan, K.; Zhang, D.; Lu, X.; Zhou, X. Simultaneous determination of ascorbic acid, dopamine and uric acid based on tryptophan functionalized graphene. Anal. Chim. Acta 2014, 823, 32-39. [CrossRef] [PubMed]

16. Wang, C.; Du, J.; Wang, H.; Zou, C.; Jiang, F.; Yang, P.; Du, Y. A facile electrochemical sensor based on reduced graphene oxide and au nanoplates modified glassy carbon electrode for simultaneous detection of ascorbic acid, dopamine and uric acid. Sens. Actuators B Chem. 2014, 204, 302-309. [CrossRef]

17. Yu, Y.; Chen, Z.; Zhang, B.; Li, X.; Pan, J. Selective and sensitive determination of uric acid in the presence of ascorbic acid and dopamine by pdda functionalized graphene/graphite composite electrode. Talanta 2013, 112, 31-36. [CrossRef] [PubMed] 
18. Wang, Y.; Bi, C. Simultaneous electrochemical determination of ascorbic acid, dopamine and uric acid using poly (tyrosine)/functionalized multi-walled carbon nanotubes composite film modified electrode. J. Mol. Liq. 2013, 177, 26-31. [CrossRef]

19. Noroozifar, M.; Khorasani-Motlagh, M.; Jahromi, F.Z.; Rostami, S. Sensitive and selective determination of uric acid in real samples by modified glassy carbon electrode with holmium fluoride nanoparticles/multi-walled carbon nanotube as a new biosensor. Sens. Actuators B Chem. 2013, 188, 65-72. [CrossRef]

20. Wang, Z.; Xia, J.; Zhu, L.; Zhang, F.; Guo, X.; Li, Y.; Xia, Y. The fabrication of poly (acridine orange)/graphene modified electrode with electrolysis micelle disruption method for selective determination of uric acid. Sens. Actuators B Chem. 2012, 161, 131-136. [CrossRef]

21. Wang, G.; Meng, J.; Liu, H.; Jiao, S.; Zhang, W.; Chen, D.; Fang, B. Determination of uric acid in the presence of ascorbic acid with hexacyanoferrate lanthanum film modified electrode. Electrochim. Acta 2008, 53, 2837-2843. [CrossRef]

22. Ojani, R.; Raoof, J.-B.; Maleki, A.A.; Safshekan, S. Simultaneous and sensitive detection of dopamine and uric acid using a poly(l-methionine)/gold nanoparticle-modified glassy carbon electrode. Chin. J. Catal. 2014, 35, 423-429. [CrossRef]

23. Chen, K.; Wang, M.; Li, G.; He, Q.; Liu, J.; Li, F. Spherical $\alpha-\mathrm{MnO}_{2}$ Supported on N-KB as Efficient Electrocatalyst for Oxygen Reduction in Al-Air Battery. Materials 2018, 11, 601. [CrossRef] [PubMed]

24. Wang, M.; Chen, K.; Liu, J.; He, Q.; Li, G.; Li, F. Efficiently Enhancing Electrocatalytic Activity of $\alpha-\mathrm{MnO}_{2}$ Nanorods/N-Doped Ketjenblack Carbon for Oxygen Reduction Reaction and Oxygen Evolution Reaction Using Facile Regulated Hydrothermal Treatment. Catalysts 2018, 8, 138. [CrossRef]

25. Akimoto, K.; Ishizuka, S.; Yanagita, M.; Nawa, Y.; Paul, G.K.; Sakurai, T. Thin film deposition of $\mathrm{Cu}_{2} \mathrm{O}$ and application for solar cells. Sol. Energy 2006, 80, 715-722. [CrossRef]

26. Poizot, P.; Laruelle, S.; Grugeon, S.; Dupont, L.; Tarascon, J.-M. Cheminform abstract: Nano-sized transition-metal oxides as negative-electrode materials for lithium-ion batteries. ChemInform 2001, 32, 496-499. [CrossRef]

27. Zhang, H.; Zhu, Q.; Zhang, Y.; Wang, Y.; Zhao, L.; Yu, B. Inside front cover: One-pot synthesis and hierarchical assembly of hollow $\mathrm{Cu}_{2} \mathrm{O}$ microspheres with nanocrystals-composed porous multishell and their gas-sensing properties. Adv. Funct. Mater. 2007, 17, 2766-2771. [CrossRef]

28. Hua, Q.; Shang, D.; Zhang, W.; Chen, K.; Chang, S.; Ma, Y.; Jiang, Z.; Yang, J.; Huang, W. Morphological evolution of $\mathrm{Cu}_{2} \mathrm{O}$ nanocrystals in an acid solution: Stability of different crystal planes. Langmuir 2011, 27, 665-671. [CrossRef] [PubMed]

29. Xu, F.; Deng, M.; Li, G.; Chen, S.; Wang, L. Electrochemical behavior of cuprous oxide-reduced graphene oxide nanocomposites and their application in nonenzymatic hydrogen peroxide sensing. Electrochim. Acta 2013, 88, 59-65. [CrossRef]

30. Li, Y.; Zhong, Y.; Zhang, Y.; Weng, W.; Li, S. Carbon quantum dots/octahedral $\mathrm{Cu}_{2} \mathrm{O}$ nanocomposites for non-enzymatic glucose and hydrogen peroxide amperometric sensor. Sens. Actuators B Chem. 2015, 206, 735-743. [CrossRef]

31. Cao, H.; Yang, A.; Li, H.; Wang, L.; Li, S.; Kong, J.; Bao, X.; Yang, R. A non-enzymatic glucose sensing based on hollow cuprous oxide nanospheres in a nafion matrix. Sens. Actuators B Chem. 2015, 214, 169-173. [CrossRef]

32. Yuan, B.; Xu, C.; Liu, L.; Zhang, Q.; Ji, S.; Pi, L.; Zhang, D.; Huo, Q. $\mathrm{Cu}_{2} \mathrm{O} / \mathrm{NiO}_{\mathrm{x}} /$ graphene oxide modified glassy carbon electrode for the enhanced electrochemical oxidation of reduced glutathione and nonenzyme glucose sensor. Electrochim. Acta 2013, 104, 78-83. [CrossRef]

33. Zhang, F.; Li, Y.; Gu, Y.; Wang, Z.; Wang, C. One-pot solvothermal synthesis of a $\mathrm{Cu}_{2} \mathrm{O} / \mathrm{graphene}$ nanocomposite and its application in an electrochemical sensor for dopamine. Microchim. Acta 2011, 173, 103-109. [CrossRef]

34. He, Q.; Liu, J.; Liu, X.; Li, G.; Deng, P.; Liang, J. Preparation of $\mathrm{Cu}_{2} \mathrm{O}$-Reduced Graphene Nanocomposite Modified Electrodes towards Ultrasensitive Dopamine Detection. Sensors 2018, 18, 199. [CrossRef] [PubMed]

35. He, Q.; Liu, J.; Liu, X.; Li, G.; Chen, D.; Deng, P.; Liang, J. Fabrication of Amine-Modified Magnetite-Electrochemically Reduced Graphene Oxide Nanocomposite Modified Glassy Carbon Electrode for Sensitive Dopamine Determination. Nanomaterials 2018, 8, 194. [CrossRef] [PubMed] 
36. Ye, X.; Gu, Y.; Wang, C. Fabrication of the $\mathrm{Cu}_{2} \mathrm{O} /$ polyvinyl pyrrolidone-graphene modified glassy carbon-rotating disk electrode and its application for sensitive detection of herbicide paraquat. Sens. Actuators B Chem. 2012, 173, 530-539. [CrossRef]

37. Zhang, X.; Wang, G.; Gu, A.; Wu, H.; Fang, B. Preparation of porous $\mathrm{Cu}_{2} \mathrm{O}$ octahedron and its application as 1-tyrosine sensors. Solid State Commun. 2008, 148, 525-528. [CrossRef]

38. Ning, J.; He, Q.; Luo, X.; Wang, M.; Liu, D.; Wang, J. Rapid and Sensitive Determination of Vanillin Based on a Glassy Carbon Electrode Modified with $\mathrm{Cu}_{2} \mathrm{O}$-Electrochemically Reduced Graphene Oxide Nanocomposite Film. Sensors 2018, 18, 2762. [CrossRef] [PubMed]

39. He, Q.; Liu, J.; Liu, X.; Xia, Y.; Li, G.; Deng, P.; Chen, D. Novel Electrochemical Sensors Based on Cuprous Oxide-Electrochemically Reduced Graphene Oxide Nanocomposites Modified Electrode toward Sensitive Detection of Sunset Yellow. Molecules 2018, 23, 2130. [CrossRef] [PubMed]

40. Shishiyanu, S.T.; Shishiyanu, T.S.; Lupan, O.I. Novel $\mathrm{NO}_{2}$ gas sensor based on cuprous oxide thin films. Sens. Actuators B Chem. 2006, 113, 468-476. [CrossRef]

41. Geim, A.K. Graphene: Status and prospects. Science 2009, 324, 1530-1534. [CrossRef] [PubMed]

42. Long, J.; Dong, J.; Wang, X.; Ding, Z.; Zhang, Z.; Wu, L.; Li, Z.; Fu, X. Photochemical synthesis of submicronand nano-scale $\mathrm{Cu}_{2} \mathrm{O}$ particles. J. Colloid Interface Sci. 2009, 333, 791-799. [CrossRef] [PubMed]

43. Laviron, E. Adsorption, autoinhibition and autocatalysis in polarography and in linear potential sweep voltammetry. J. Electroanal. Chem. Interfacial Electrochem. 1974, 52, 355-393. [CrossRef]

(C) 2018 by the authors. Licensee MDPI, Basel, Switzerland. This article is an open access article distributed under the terms and conditions of the Creative Commons Attribution (CC BY) license (http://creativecommons.org/licenses/by/4.0/). 